\title{
PERIOPERATIVE BETA BLOCKER IN HIGH RISK PATIENTS UNDERGOING MAJOR ABDOMINAL SURGERY AND ITS EFFECT ON CARDIOVASCULAR MORTALITY AND MORBIDITY
}

\author{
Gehan Fouad Kamel, Adel Mohamad Alansary, Hoda Shokry Abdelsamie, Rasha \\ Mahmoud Hassan, Lydia Edward Aziz Zakhary
}

\begin{abstract}
Department of Anesthesia, Intensive Care and Pain Management, Faculty of Medicine, Ain Shams University, Cairo - Egypt.

Corresponding author:

Lydia Edward Aziz Zakhary

Mobile: 01222555128

E mail:

lydia_zakhary@hotmail.com

Received: 30/4/2019

Accepted: 28 /5/2019

Background: Perioperative cardiac complications are an important concern for the millions of individuals who undergo surgery worldwide every year. After surgery, $2 \%$ of these patients suffer major cardiac complications.

Aim of the Work: To study the effects of perioperatively administered beta-blockers for prevention of surgery-related mortality and morbidity in patients undergoing major abdominal surgery while under general anesthesia.

Patients and Methods: This is an observational prospective study, in which 240 patients were divided into 2 groups (120 patients each) as follows: Beta blocker group (BB group) 120 patients on beta blocker (Bisoprolol $5 \mathrm{mg}$ ) started more than 15 days preoperative and continued for at least 7 days postoperative. Control group: 120 patients not receiving any beta blocker.

Results: In this study, results showed no difference between 2 groups regarding cerebrovascular events and heart failure. Equal cases of mortality happened to patients in both groups. As regards hypothension with $S B P<90 \mathrm{mmHg}$, we found that it occurred to 32 patients representing $26.7 \%$ of beta blocker group, compared to 18 patients representing $15 \%$ of the control group.

Conclusion: Analysis of the results concluded that Patients on beta blocker are at less risk of perioperative arrhythmias and myocardial infarction when undergoing high risk surgeries. These patients are at higher risk of experiencing episodes of bradycardia and hypotension. No significant effect on perioperative heart failure, cerebrovascular stroke and mortality.
\end{abstract}

Keywords: Ischemic heart disease, Beta blocker, Peri Operative ISchemic Evaluation

\section{INTRODUCTION:}

Worldwide it is estimated that around 200 million people undergo non-cardiac surgery annually. Cardiovascular complications account for majority of the cause of postoperative morbidity and mortality with incidence ranging from $0.5 \%$ to $30 \%{ }^{(1)}$.

Non-cardiac surgery causes a rise in catecholamine concentrations that results in an increase in heart rate, blood pressure, and free fatty acid concentrations, which in turn increases myocardial oxygen demand. The cardiovascular effects of general anesthesia include changes in the arterial and central venous pressures, cardiac output, and varying heart rhythms, which occur by the following mechanisms: decreased systemic vascular resistance, decreased myocardial contractility, decreased stroke volume, and 


\section{Gehan Fouad Kamel, et al.,}

increased myocardial irritability. Induction of general anesthesia lowers systemic arterial pressures by $20-30 \%$, tracheal intubation increases the blood pressure by 20-30 $\mathrm{mm} \mathrm{Hg}$, and inhalational agents lower cardiac output by $15 \%{ }^{(2)}$.

A previously stable patient may decompensate postoperatively, leading to significant postoperative morbidity and mortality. A substantial number of all deaths among patients undergoing non cardiac surgery are caused by cardiovascular complications $^{(3)}$.

The high prevalence of cardiac events associated with non cardiac surgery reflects the high prevalence of underlying Coronary artery disease in the general population, upon which the additional stresses of surgery are overlaid ${ }^{(4)}$.

The pathophysiology of perioperative myocardial infarction is complex, but may include myocardial oxygen demand/supply mismatch associated with tachycardia, hypertension, and pain ${ }^{(5)}$.

\section{AIM OF THE WORK:}

To study the effects of perioperatively administered beta-blockers for prevention of surgery-related mortality and morbidity in patients undergoing major abdominal surgery while under general anesthesia.

\section{PATIENTS AND METHODS:}

After approval of the ethical committee of Ain Shams University, Patients who were enrolled in this study were chosen from those attending pre-anesthesia check up visits in Ain Shams university hospitals. A written, informed and valid consent was obtained from every patient after proper explanation of the study procedure and the expected outcome in a clear language.

Inclusion Criteria: Adult patients of either sex, aged 50-70 years. History of ischemic heart disease or having 2 or more risk factors for ischemic heart disease (hypertension, DM, obesity BMI > 30, smoking, hyperlipidemia, family history, stress, sedentary life style). Elective major abdominal surgery under general anesthesia. Expected surgery time more than 1 hour.

Exclusion Criteria: History of previous open heart surgery. Patients with bronchial asthma. Patients with heart failure. Patients with significant valve lesion (mitral stenosis with mitral valve area $<2 \mathrm{~cm} 2$, aortic stenosis with aortic valve area $<0.9 \mathrm{~cm} 2$ or severe aortic or mitral regurge) on echocardiography. Ejection fraction $<40 \%$. Patients with previous cerebro- vascular stroke. Preoperative hemoglobin level $<10 \mathrm{gm} \%$. Preoperative patient heart rate $<$ $45 \mathrm{bpm}$. Preoperative patient systolic blood pressure $<100 \mathrm{mmHg}$. Emergency surgery. Massive intraoperative blood loss. Intraoperative hemodynamic instability. Prolonged surgery time $>8$ hours. Needing for re-exploration in the first week postoperative period. Needing for inotropic support intraoperative or in the post operative period.

This is an observational prospective non concurrent study, in which 240 patients were divided into 2 groups (120 patients each) as follows: Beta blocker group (B group): 120 patients on beta blocker (Bisoprolol 5 $\mathrm{mg}$ ) started more than 15 days preoperative and continued for at least 7 days postoperative. Control group (C group): 120 patients not receiving any betablocker.

All patients were closely monitored for the possible cardiovascular mortality and morbidity as: Death (either cardiac or non cardiac). Non fatal myocardial infarction. Acute stroke. Arrhythmia. Heart failure. Significant hypotension (SBP $<100)$. Significant bradycardia (HR $<45$ bpm)

\section{Anesthetic Technique:}

Preoperative: Pre-operative assessment of the patient was done, full detailed history 
was taken, pre-operative labs such as $\mathrm{CBC}$, full coagulation profile, kidney function tests, liver function tests, ECG, echocardiography and chest X-ray were checked. Demographic data as age, weight, and sex were recorded. The basal heart rate (HR), noninvasive arterial systolic blood pressure (SBP) and diastolic blood pressure (DBP), and peripheral oxygen saturation (SpO2) were recorded. The usual daily dose of beta blocker was taken till the morning of the operation.

Intraoperative: An $18 \mathrm{G}$ peripheral cannula was inserted and conventional general anesthesia was induced for all patients using: 1-2 mic / $\mathrm{kg}$ fentanyl, 1-1.5 $\mathrm{mg} / \mathrm{kg}$ propofol, $0.5 \mathrm{mg} / \mathrm{kg}$ atracurium are given, endotracheal intubation and volume controlled mechanical ventilation started. General anesthesia was maintained by 1 MAC isoflurane and $0.1 \mathrm{mg} / \mathrm{kg}$ atracuruim every 20-30 min and adequate intraoperative analgesia. After induction, a urinary catheter, a central venous catheter and a radial arterial cannula were inserted. Close monitoring of heart rate, invasive blood pressure, peripheral oxygen saturation and recorded every 5 minutes. Central venous pressure, urine output and blood loss are monitored and recorded every hour.

Postoperative: After fulfilling criteria of complete recovery, all patients were extubated and transferred to ICU for close monitoring. ensuring that the usual daily dose of beta blocker should be restarted the next day postoperative and continued for at least 1 week postoperative.

\section{Patients were monitored for 7 days with} the following:

1- Vital data: was monitored closely for 7 days. Any significant hypotension (SBP $<100 \mathrm{mmHg}$ ), and significant bradycardia (HR $<45$ bpm) were recorded. Significant hypotension was primarily treated with IV fluids resuscitation. Cases not responding to IV fluids and necessitating adding IV vasopressor (Noradrenaline) were excluded from the study. Significant bradycardia were closely monitored, if prolonged and affecting tissue perfusion, BB needed to be discontinued and 0.6-1 mg atropine given. On the other hand, tachycardia with $\mathrm{HR}>100 \mathrm{bpm}$ was aggressively investigated and treated accordingly: Ensuring adequate analgesia with IV paracetamol $1 \mathrm{gm} / 6-8 \mathrm{hrs}$ and low dose narcotics if needed. Ensuring good hydration with IV crystalloids to maintain CVP 8-12 $\mathrm{cmH} 2 \mathrm{O}$. Ensuring that there is no surgical cause (bleeding or leakage) by reassessing surgical wound and drains. Hypertension with SBP $>150 \mathrm{mmHg}$ for 3 successive readings after exclusion of postoperative pain by providing good analgesia was treated by addition of antihypertensive dose of calcium channel blocker (amlodipine $5 \mathrm{mg}$ daily)

2- 12-leads ECG: was done 6 hours and 12 hours postoperative and then every 24 hours till day 7. Any changes in rate or rhythm or signs of ischemia were recorded.

3- CKtotal, CK-MB, Troponin: Were done daily till day 7 . when positive, they were repeated after 8 hours for confirmation of myocardial infarction. When diagnosis of acute MI was established, patient was treated by antiplatlets (aspirin $150 \mathrm{mg}$ ), analgesic (morphine $0.1 \mathrm{mg} / \mathrm{kg}$ ), $\mathrm{O} 2$ administration and good monitoring.

4- Echocardiography: was done if there is any positive event (elevated cardiac enzymes or signs and symptoms of heart failure) and any new changes different from baseline echocardiography will be recorded.

\section{5- Assessment of heart failure: Clinical} assessment: Elevated central venous pressure, congested neck veins, pulmonary congestion, lower limb edema, cold extremities, hypotension.

Laboratory assessment: $\beta$-Natriuretic peptide $(\beta \mathrm{NP})$ : It is generated by cardiomyocytes due to myocardial stretch. Its elevated levels indicates heart failure. 


\section{Gehan Fouad Kamel, et al.,}

Troponin: Elevated levels indicates myocardial injury.

Imaging: Chest $\mathrm{x}$-ray to assess heart size and pulmonary congestion and to detect alternative cardiac, pulmonary, and other diseases that may cause or contribute to the patient's symptoms. 2-dimensional echocardiogram with Doppler was performed to assess ventricular function, size, wall thickness, wall motion, and valve function. When diagnosis of heart failure was confirmed, antifailure measures started with diuretics and low dose ACEIs.

\section{Assessment of stroke:}

\section{a) Clinical assessment:}

National Institutes of Health Stroke Scale (according to AHA/ASA guidelines 2018) ${ }^{(6)}$.

Imaging: MRI brain is done if suspected stroke. And if diagnosis of stroke was confirmed, patient was treated with palliative medications and intubation and ventilation once indicated ${ }^{(6)}$.

Need to stop the drug in the post operative period for any reason was recorded:

\section{Statistical method:}

Statistical presentation and analysis of the present study was conducted, using the mean, standard Deviation, unpaired student t-test and chi-square tests by (IBM SPSS Statistics for Windows, Version 20.0. Armonk, NY: IBM Corp.). Unpaired Student T-test was used to compare between tow groups in quantitative data.

Chi-square: The hypothesis that the row and column variables are independent, without indicating strength or direction of the relationship. Pearson chi-square and likelihood-ratio chi-square. Fisher's exact test and Yates' corrected chi-square are computed for $2 \times 2$ tables.

\section{RESULTS:}

Table (1): Demographic data (Age, sex and weight).

\begin{tabular}{|c|c|c|c|c|}
\hline \multirow{2}{*}{ Demographic data } & \multirow{2}{*}{$\begin{array}{c}\text { BB } \\
(\mathrm{N}=120)\end{array}$} & \multirow{2}{*}{$\begin{array}{c}\text { Control } \\
(\mathrm{N}=120)\end{array}$} & \multicolumn{2}{|c|}{ Tests } \\
\hline & & & $\mathrm{t} / \mathrm{X}^{2}$ & P-value \\
\hline \multicolumn{5}{|l|}{ Age (years) } \\
\hline Range & $50-67$ & $52-70$ & \multirow[t]{2}{*}{0.837} & \multirow[t]{2}{*}{0.404} \\
\hline Mean \pm SD & $61.54 \pm 4.26$ & $62.05 \pm 5.14$ & & \\
\hline \multicolumn{5}{|l|}{ Sex } \\
\hline Female & $58(48.3 \%)$ & $47(39.2 \%)$ & \multirow[t]{2}{*}{1.693} & \multirow[t]{2}{*}{0.193} \\
\hline Male & $62(51.7 \%)$ & $73(60.8 \%)$ & & \\
\hline \multicolumn{5}{|l|}{ Weight (kg) } \\
\hline Range & $25-39$ & $28-37$ & \multirow[t]{2}{*}{1.284} & \multirow[t]{2}{*}{0.201} \\
\hline Mean \pm SD & $34.25 \pm 8.52$ & $32.89 \pm 7.88$ & & \\
\hline
\end{tabular}

Table (2): Incidence of bradycardia in beta blocker group and control group.

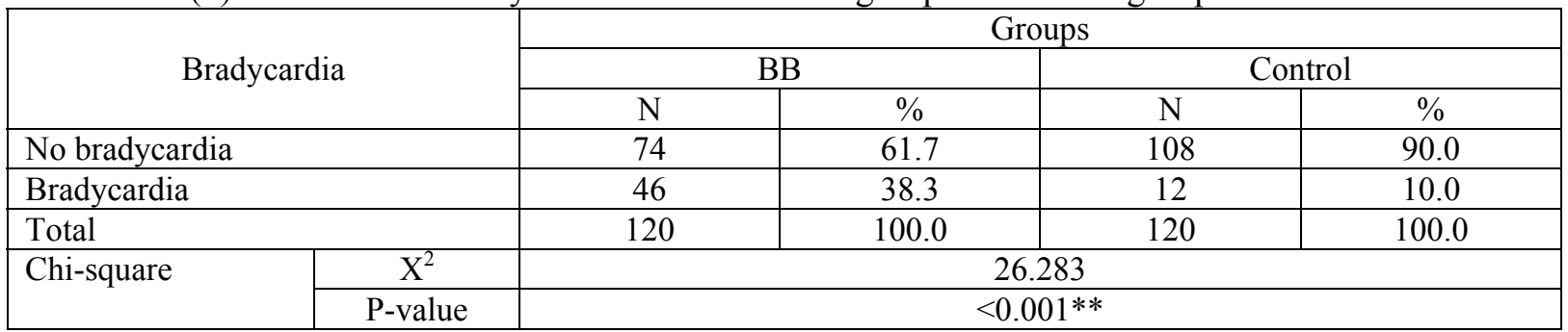


Perioperative Beta Blocker In High Risk Patients Undergoing Major Abdominal Surgery And ....

Table (3): Incidence of arrythmia in beta blocker group and control group.

\begin{tabular}{|c|c|c|c|c|c|}
\hline \multirow{3}{*}{\multicolumn{2}{|c|}{ Arrythmia }} & \multicolumn{4}{|c|}{ Groups } \\
\hline & & \multicolumn{2}{|c|}{ BB } & \multicolumn{2}{|c|}{ Control } \\
\hline & & $\mathrm{N}$ & $\%$ & $\mathrm{~N}$ & $\%$ \\
\hline \multicolumn{2}{|c|}{ No arrythmia } & 104 & 86.7 & 72 & 60.0 \\
\hline \multicolumn{2}{|c|}{ Arrythmia } & 16 & 13.3 & 48 & 40.0 \\
\hline \multicolumn{2}{|c|}{ Total } & 120 & 100.0 & 120 & 100.0 \\
\hline \multirow[t]{2}{*}{ Chi-square } & $\mathrm{X}^{2}$ & \multicolumn{4}{|c|}{21.818} \\
\hline & P-value & \multicolumn{4}{|c|}{$<0.001 * *$} \\
\hline
\end{tabular}

Table (4): Incidence of stroke in beta blocker group and control group.

\begin{tabular}{|c|c|c|c|c|c|}
\hline \multirow{3}{*}{\multicolumn{2}{|c|}{ Stroke }} & \multicolumn{4}{|c|}{ Groups } \\
\hline & & \multicolumn{2}{|c|}{ BB } & \multicolumn{2}{|c|}{ Control } \\
\hline & & $\mathrm{N}$ & $\%$ & $\mathrm{~N}$ & $\%$ \\
\hline \multicolumn{2}{|c|}{ No stroke } & 118 & 98.3 & 118 & 98.3 \\
\hline \multicolumn{2}{|c|}{ Stroke } & 2 & 1.7 & 2 & 1.7 \\
\hline \multicolumn{2}{|c|}{ Total } & 120 & 100.0 & 120 & 100.0 \\
\hline \multirow[t]{2}{*}{ Chi-square } & $\mathrm{X}^{2}$ & \multicolumn{4}{|c|}{0.000} \\
\hline & P-value & \multicolumn{4}{|c|}{1.000} \\
\hline
\end{tabular}

Table (5): Incidence of myocardial infarction in beta blocker group and control group.

\begin{tabular}{|c|c|c|c|c|c|}
\hline \multirow{3}{*}{\multicolumn{2}{|c|}{ MI }} & \multicolumn{4}{|c|}{ Groups } \\
\hline & & \multicolumn{2}{|c|}{ BB } & \multicolumn{2}{|c|}{ Control } \\
\hline & & $\mathrm{N}$ & $\%$ & $\mathrm{~N}$ & $\%$ \\
\hline \multicolumn{2}{|c|}{ No MI } & 112 & 93.3 & 108 & 90.0 \\
\hline \multicolumn{2}{|c|}{ MI } & 8 & 6.7 & 12 & 10.0 \\
\hline \multicolumn{2}{|c|}{ Total } & 120 & 100.0 & 120 & 100.0 \\
\hline \multirow[t]{2}{*}{ Chi-square } & $\mathrm{X}^{2}$ & \multicolumn{4}{|c|}{0.873} \\
\hline & P-value & \multicolumn{4}{|c|}{0.350} \\
\hline
\end{tabular}

Table (6): Incidence of heart failure in beta blocker group and control group.

\begin{tabular}{|c|c|c|c|c|c|}
\hline \multirow{3}{*}{\multicolumn{2}{|c|}{$\mathrm{HF}$}} & \multicolumn{4}{|c|}{ Groups } \\
\hline & & \multicolumn{2}{|c|}{$\mathrm{BB}$} & \multicolumn{2}{|c|}{ Control } \\
\hline & & $\mathrm{N}$ & $\%$ & $\mathrm{~N}$ & $\%$ \\
\hline \multicolumn{2}{|c|}{ No HF } & 117 & 97.5 & 118 & 98.3 \\
\hline \multicolumn{2}{|c|}{$\mathrm{HF}$} & 3 & 2.5 & 2 & 1.7 \\
\hline \multicolumn{2}{|c|}{ Total } & 120 & 100.0 & 120 & 100.0 \\
\hline \multirow[t]{2}{*}{ Chi-square } & $x^{2}$ & \multicolumn{4}{|c|}{0.204} \\
\hline & P-value & \multicolumn{4}{|c|}{0.651} \\
\hline
\end{tabular}

Table (7): Incidence of hypotension in beta blocker group and control group.

\begin{tabular}{|c|c|c|c|c|c|}
\hline \multirow{3}{*}{\multicolumn{2}{|c|}{$\mathrm{BP}<100$}} & \multicolumn{4}{|c|}{ Groups } \\
\hline & & \multicolumn{2}{|c|}{ BB } & \multicolumn{2}{|c|}{ Control } \\
\hline & & $\mathrm{N}$ & $\%$ & $\mathrm{~N}$ & $\%$ \\
\hline \multicolumn{2}{|c|}{$\mathrm{BP}>100$} & 88 & 73.3 & 102 & 85.0 \\
\hline \multicolumn{2}{|c|}{$\mathrm{BP}<100$} & 32 & 26.7 & 18 & 15.0 \\
\hline \multicolumn{2}{|c|}{ Total } & 120 & 100.0 & 120 & 100.0 \\
\hline \multirow[t]{2}{*}{ Chi-square } & $x^{2}$ & \multicolumn{4}{|c|}{4.952} \\
\hline & P-value & \multicolumn{4}{|c|}{$0.026^{*}$} \\
\hline
\end{tabular}


Table (8): Incidence of mortality cases in beta blocker group and control group.

\begin{tabular}{|c|c|c|c|c|c|}
\hline \multirow{3}{*}{\multicolumn{2}{|c|}{ Mortality }} & \multicolumn{4}{|c|}{ Groups } \\
\hline & & \multicolumn{2}{|c|}{ BB } & \multicolumn{2}{|c|}{ Control } \\
\hline & & $\mathrm{N}$ & $\%$ & $\mathrm{~N}$ & $\%$ \\
\hline \multicolumn{2}{|c|}{ Died } & 2 & 1.7 & 2 & 1.7 \\
\hline \multicolumn{2}{|c|}{ Alive } & 118 & 98.3 & 118 & 98.3 \\
\hline \multicolumn{2}{|c|}{ Total } & 120 & 100.0 & 120 & 100.0 \\
\hline \multirow[t]{2}{*}{ Chi-square } & $x^{2}$ & \multicolumn{4}{|c|}{0.000} \\
\hline & P-value & \multicolumn{4}{|c|}{1.000} \\
\hline
\end{tabular}

\section{DISCUSSION:}

This study was performed on 240 patients undergoing major abdominal surgery. Seven outcomes were studied comparing perioperative mortality and morbidity occurring in patients receiving beta blockers to patients not receiving any beta blockers.

In this study, it was noticed that bradycardia with HR less than 45 bpm happened in 46 patients ( $38.3 \%$ of patients) in beta blocker group compared to 12 patients $(10 \%$ of patients) in the control group.

When evaluating trials investigating bradycardia, it was noticed that bradycardia was defined very differently by study authors. Some classified a heart rate below 60 beats per minute as bradycardia,

Whereas others detected an episode of bradycardia only if heart rate fell below 40 beats per minute, or if bradycardia required treatment. These different thresholds for bradycardia are likely to have caused clinical and statistical heterogeneity ${ }^{(7)}$.

In a metaanalysis of 8 studies done by Blessberger et al ${ }^{(7)}$ including 660 patients undergoing cardiac surgery, they found no clear evidence of an effect of beta-blockers on episodes of bradycardia in the setting of heart surgery (RR1.61, 95\%CI 0.97 to 2.66 , $P$ value 0.06$)$.

Regarding non cardiac surgery, several studies were done to evaluate the effect of beta blocker on bradycardia. in the POBBLE 2005, 103 patients undergoing infrarenal vascular surgery among which bradycardia occurred to 30 out of 53 patients receiving beta blocker $(15.9 \%)$ compared to 6 out of 44 patients $(2.6 \%)$ of the patients in the control group ${ }^{(8)}$.

Also in another study done on a large number of patients the POISE study (Perioperative ischemic evaluation) 2008., 8531 patients undergoing non cardiac surgery, it was noticed that bradycardia occurred in $6.6 \%$ in the betablocker group compared to $2 \%$ in the control group and it was concluded that beta blocker therapy would result in excess of 42 patients experiencing clinically significant bradycardia for every 1000 treated $^{(9)}$.

In contrast, the results obtained by a study made by Moon et al. ${ }^{(10)}$ showed no significant difference between betablocker group and control group as regards occurence of bradycardia.

Regarding the occurrence of arrhythmia either ventricular or supraventricular. It was found in the beta blocker group, that arrythmia occurred in 16 out of 120 patients representing $13.3 \%$ compared to the control group in which it occurred to 48 out of 120 patients representing $40 \%$ of the patients in the control group.

Results was found to show significant difference favoring beta blocker in reducing these arrhythmias.

These results were concomittent to those of a study made by De Azevedo et al. on 100 patients undergoing cardiac surgery, supraventricular arrythmia occurred to $11 \%$ 
of patients on beta blocker compared to 24 $\%$ of patients in the control group ${ }^{(11)}$.

Also beta blocker significantly reduces ventricular arrythmias and extrasystoles in patients undergoing cardiac surgery, as shown in a study by Sun et al. ${ }^{(12)}$.

In the POBBLE study done in 2005, which was a double-blind randomized placebo-controlled trial, participants were 103 patients without previous myocardial infarction who had infrarenal vascular surgery . patients were closely monitored by ECG Holter for $72 \mathrm{Hrs}$ postoperatively . and the results showed no significant protective effect of beta blocker between 2 groups ${ }^{(8)}$.

The POISE study done in 2008 was done on a large number of patients and found that arrhythmia occurred to $2.1 \%$ of patients on beta blocker compared to $2.8 \%$ of the control group ${ }^{(9)}$.

Another study done in 2006 by Lai et al shows more significant difference between the 2 groups of patients diagnosed with oesophageal cancer. The esophageal cancer patients, no less than 65 years old, scheduled for elective esophagectomy were enrolled, and randomized into metoprolol group and control group. The patients of metoprolol group received metoprolol to control heart rate from anesthesia induction to $72 \mathrm{~h}$ after operation. The results showed that patients enrolled in the beta blocker did not experience arrhythmias compared to 4 out of 30 cases in the control group ${ }^{(13)}$.

In this study, results showed no difference between 2 groups regarding cerebrovascular events. When comparing this results to previous studies, we found that Five studies evaluated cerebrovascular events in non-cardiac surgery $(9150$ participants). Only the largest of the five trials found a significant increase in cerebrovascular events in the beta-blocker group compared with the control group at an alpha level of 0.05 , in contrast to the results concluded by the present study which showed no significant difference.

In contrast, the other four trials yielded non-significant results. Overall, we found no clear evidence of an effect of beta-blockers on cerebrovascular events in non-cardiac surgery ${ }^{(14,15)}$.

Regarding myocardial infarction, it was found that the protective effect of beta blocker was statistically insignificant. when comparing our results to previous studies, we found no AMI occurred in the betablocker group nor in the control group in a study done by Lai et al. ${ }^{(6)}$ in 2006 this study included small number of oesophageal cancer patients. Other trials found no statistically significant difference between the beta-blocker group and the control group at an alpha level of 0.05 .

Only the large POISE trial Devereaux et al. ${ }^{(16)}$ could identify a protective effect of beta-blockers. This single trial had a weight of $80 \%$ in a meta-analysis done by Blessberger et al. ${ }^{(7)}$. Overall, beta-blockers statistically significantly reduced perioperative AMI by $27 \%$ in non-cardiac surgery ${ }^{(7)}$.

The results of this study show no significant effect of beta blocker on the occurrence of heart failure in the perioperative period in non cardiac surgery. comparing the obtained results to many studies included in the meta analysis done by Blessberger et al. $^{(7)}$ who also found no evidence of an effect of beta-blockers on the occurrence of congestive heart failure (RR $1.18,95 \%$ CI 0.94 to 1.48 , P value 0.16 ) The effect of beta blocker treatment remained non-significant throughout all subgroup analyses in that study.

The findings obtained from the present study are also consistent with results of the meta-analysis by Bangalore and colleagues. Likewise, the review authors could not find an interaction between beta-blocker intake 


\section{Gehan Fouad Kamel, et al.,}

and development of perioperative congestive heart failure ${ }^{(17)}$.

A meta-analysis of 22 trials $(10,947$ participants) in non-cardiac surgery indicated that beta-blockers significantly increased hypotensive episodes (RR 1.50, $95 \%$ CI 1.38 to $1.64, \mathrm{P}$ value $<0.00001$ ) This effect remained unchanged and consistent throughout all subgroup analyses $^{(7)}$.

These results are similar to the results obtained by the present study. It was also concluded a significant increase in episodes of hypotension in patients.

These results were different than those obtained by a study made by Moon et al and another study by shukla et al which showed no significant difference between beta blocker and control group as regards occurrence of hypotensio ${ }^{(10,18)}$.

Results from two other meta-analyses were within the same range compared with the present estimate: Bangalore and colleagues found a $62 \%$ increase in hypotensive episodes (OR 1.62, 95\% CI 1.44 to $1.82, \mathrm{P}$ value $<0.0001$; Bangalore ${ }^{(17)}$, and meta-analysis of 'secure' RCTs by Bouri and colleagues revealed a 51\%rise in hypotension in the beta-blocker group (RR $1.51,95 \%$ CI 1.37 to $1.67, \mathrm{P}$ value < $0.00001)^{(19)}$.

In the POISE trial, hypotension was the risk factor with the highest population attributable risk that caused stroke and ultimately increased mortality in patients taking beta-blockers ${ }^{(16)}$.

Also In this study, equal cases of mortality happened in both groups showing no effect of beta blocker on mortality. comparing our results to Blessberger et al. ${ }^{(7)}$ metaanalysis, which studied all cause mortality in 13 trials, in 3 studies no deaths occurred in the beta-blocker group nor in the control group ${ }^{(13,20)}$.
In the POISE trial Devereaux et al. ${ }^{(16)}$, a significant increase in mortality was observed, whereas in the remaining of the 13 trials, no significant difference was found between the beta-blocker group and the control group at an alpha level of 0.05 . Overall, it was found that beta-blockers increased perioperative mortality ${ }^{(7)}$.

\section{Conclusion:}

Patients on beta blocker are at less risk of perioperative arrhythmias and myocardial infarction when undergoing high risk surgeries. These patients are at higher risk of experiencing episodes of bradycardia and hypotension. No significant effect on perioperative heart failure, cerebrovascular stroke and mortality.

\section{REFERENCES:}

1. Bakker EJ, Ravensbergen NJ, Poldermans D. Perioperative cardiac evaluation, monitoring, and risk reduction strategies in noncardiac surgery patients. Curr Opin Crit Care. 2011;17:409-15

2. Hübner $M$, Lovely JK, Huebner $M$, Slettedahl SW, Jacob AK, Larson DW. Intrathecal Analgesia and Restrictive Perioperative Fluid Management within Enhanced Recovery Pathway: Hemodynamic Implications. J Am Coll Surg. 2013 Apr 23.

3. Augoustides JG, Neuman MD, Al-Ghofaily L, Silvay G. Preoperative cardiac risk assessment for noncardiac surgery: defining costs and risks. J Cardiothorac Vasc Anesth. 2013; 27 (2): 395-9.

4. Smeili LA and Lotufo PA. Incidence and predictors of cardiovascular complications and death after vascular surgery. Arquivos brasileiros de cardiologia. 2015; 105 (5): 510-8.

5. Meltzer AJ, Graham A, Connoly $\mathrm{PH}$, Metzer EC. The comprehensive risk assessment for Bypass (CRAB) facilitates efficient perioperative risk assessment for patients with critical limb ischemia. J Vasc Surg. 2013; 57(5):1186-1195. 
6. Powers WJ, Rabinstein AA, Ackerson T, Adeoye OM, Bambakidis NC, Becker K, Jauch EC. 2018 guidelines for the early management of patients with acute ischemic stroke: a guideline for healthcare professionals from the American Heart Association/American Stroke Association. Stroke, 2018; 49(3): 46-99.

7. Blessberger H, Kammler J, Domanovits H, Schlager O, Wildner B, Azar D, Schillinger M, Wiesbauer F, Steinwender C. Perioperative beta-blockers for preventing surgery-relatedmortality and morbidity. Cochrane Database of Systematic Reviews 2018, Issue 3. Art. No.: CD004476. DOI: 10. 1002/14651858. CD004476. pub3.

8. Brady AR, Gibbs JS, Greenhalgh RM, Powell JT, Sydes MR, POBBLE trial investigators. Perioperative betablockade (POBBLE) for patients undergoing infrarenal vascular surgery: results of a randomized double-blind controlled trial. Journal of Vascular Surgery 2005; 41(4): 602-9.

9. Devereaux PJ, Goldman L, Cook DJ, et al. Perioperative cardiac events in patients undergoing noncardiac surgery: a review of the magnitude of the problem, the pathophysiology of the events and methods to estimate and communicate risk. CMAJ $2005 ; 173: 627$.

10. Moon YE, Hwang WJ, Koh HJ, Min JY, Lee J. The sparing effect of low-dose esmolol on sevoflurane during laparoscopic gynaecological surgery. Journal of International Medical Research 2011; 39: 1861-9.

11. De Azevedo Lúcio E, Flores A, Blacher C, Leaes PE, Lucchese FA, Pinto Ribeiro J. Effectiveness of metoprolol in preventing atrial fibrillation and flutter in the postoperative period of coronary artery bypass graft surgery [Efetividade do metoprolol na prevencao de fibrilacao e flutter atrial no pos-operatorio de cirurgia de revascularizacao miocardica]. Arquivos Brasileiros de Cardiologia 2003;82(1):3741.
12. Sun J, Ding Z, Qian Y. E fect of shortacting beta blocker on the cardiac recovery after cardiopulmonary bypass. Journal of Cardiothoracic Surgery 2011;6(99).

13. Lai R, XuM, HuangW, Wang $X$, ZengW, LinW. Beneficial effects of metoprolol on perioperative cardiac function of elderly esophageal cancer patients. Chinese Journal of Cancer 2006;25(5):609-13.

14. Marwick $\mathrm{TH}$, Branagan $H$, Venkatesh $B$, Stewart S. Use of a nurse-led intervention to optimize beta-blockade for reducing cardiac events after major noncardiac surgery. American Heart Journal 2009; 157(4):78490.

15. Yang $\mathrm{X}, \mathrm{Wu} \mathrm{X}$, Wang $\mathrm{S}$, Wang Q. Effects of metoprolol on perioperative cardiovascular events in patients with risk or at high risk for coronary artery disease undergoing noncardiac surgery. Chinese Medical Journal (Zhonghua Yi Xue Za Zhi) 2008; 88 (21):1476-80.

16. Devereaux PJ, Yang H, Yusuf S, Guyatt G, Leslie K, Villar JC, et al. Effects of extended-release metoprolol succinate in patients undergoing non-cardiac surgery (POISE trial): a randomised controlled trial. Lancet 2008; 371:1839-47.

17. Bangalore S, Wetterslev J, Pranesh S, Sawhney S, Gluud C, Messerli FH. Perioperative blockers in patients having non-cardiac surgery: $\overline{\mathrm{a}}$ meta-analysis. Lancet 2008;372: 1962-76.

18. Shukla S, Gupta K, Gurha P, Sharma M, Sanjay RR, Shukla R, et al. Role of blockade in anesthesia and postoperative pain management after major lower abdominal surgery. Internet Journal of Anesthesiology 2010; 25(1): 1-7.

19. Bouri S, Shun-Shin MJ, Cole GD, Mayet J, Francis DP. Meta-analysis of secure randomised controlled trials of - blockade to prevent perioperative death in non-cardiac surgery. Heart 2014; 100 (6): 456-64.

20. Miller DR, Martineau RJ, Wynands JE, Hill J. Bolus administration of esmolol for controlling the haemodynamic response to tracheal intubation: the Canadian multicentre trial. Canadian Journal of Anesthesia 1991;38(7):849-58. 


\section{Gehan Fouad Kamel, et al.,}

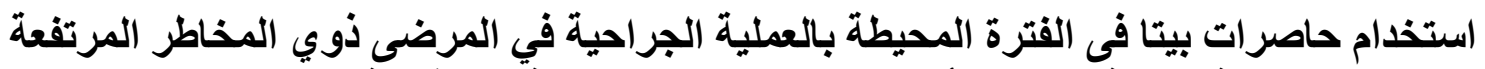

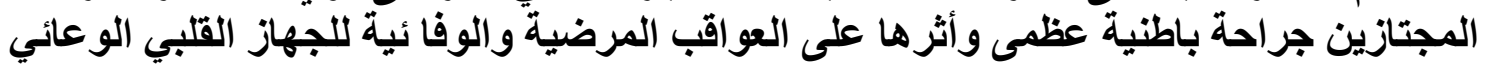

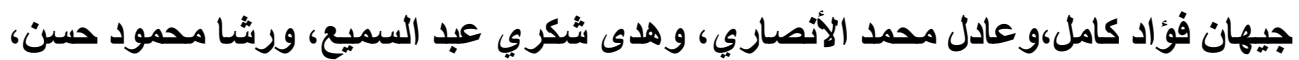

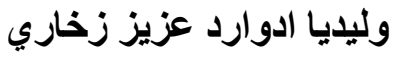

قسم التخدير و الرعاية المركزة، كلية الطب - جامعة عين شمس زدي

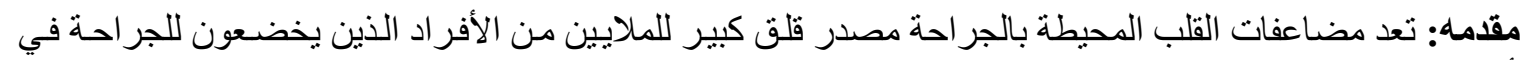

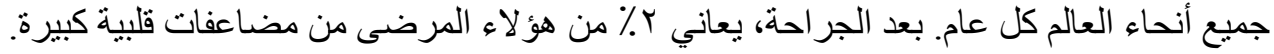

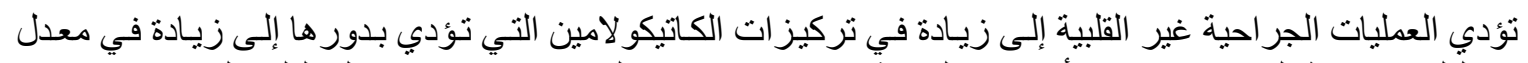
ضربات القلب وضغط الدم وتركيز ات الأحماض الدهنية، مما يؤدي بدوره إلى زيادة الحتياج عضله القلب الي الاوكسجين. تثنمل الآثار القلبية للتخدير العام تغيرات في ضغط الدم الوريدي المركزي والثرياني، و الإخر اج القلبي، و إيقاعات القلب المختلفة.

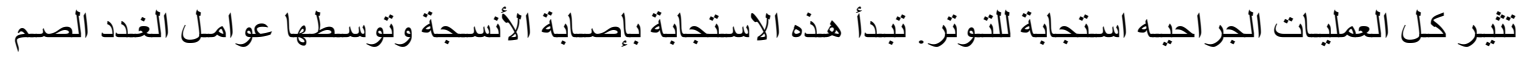

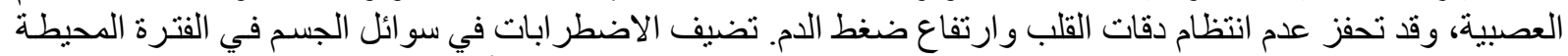

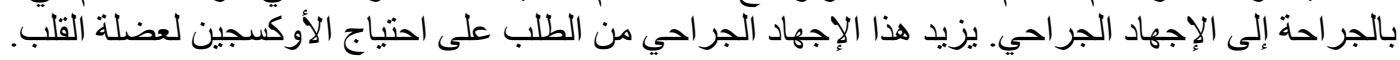

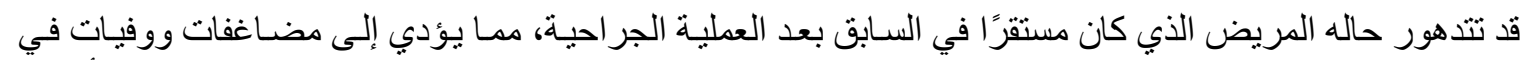

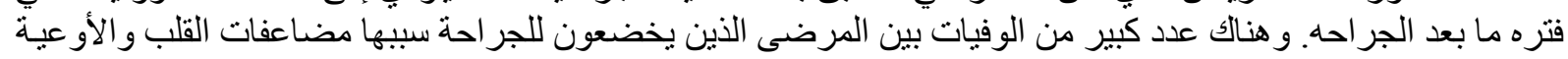
الدموية. تعتبر الفسيولوجيا المرضيةللازمه القلبيه المحيطة بالجر احة معقدة، ولكنها قد تثمل عدم تطابق الطلب / العرض على العلى

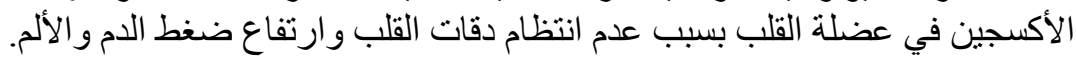

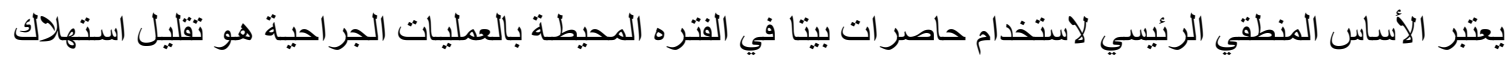

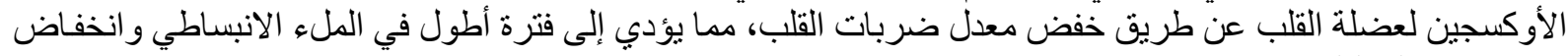
انقباض عضلة القلب. الهدف من العمل: لدر اسة آثار حاصر ات بيتا حول الجر احة للوقاية من الوفيات و المضاعفات المرتبطة بالجر احة في

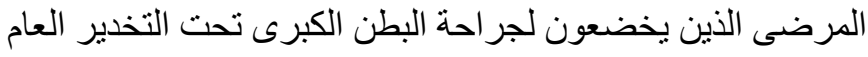

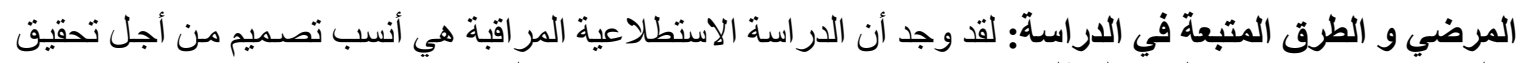

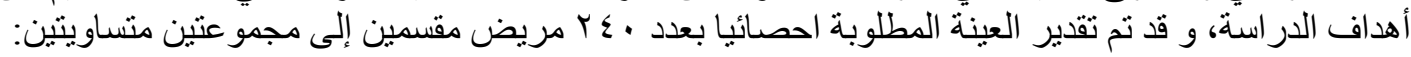

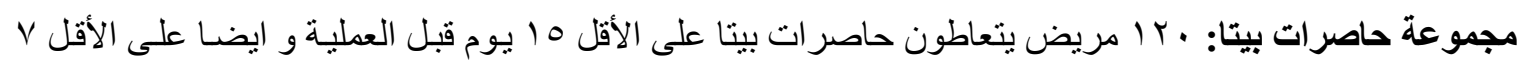
ايام بعد العملية.

مجموعة مرجعية: . با مريض لا يتعاطون اب نوع من حاصرات بيتا. تم المتابعة الدقيقة لجميع المرضى للعوقب المرضية و الوفائية للجهاز القلبي الوعائي منها:

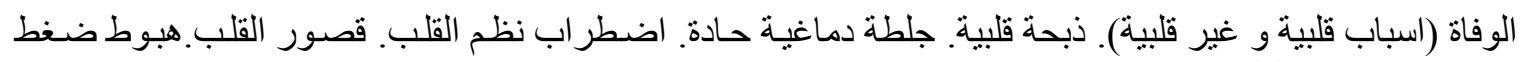
الدم. انخفاض ضربات القلب.

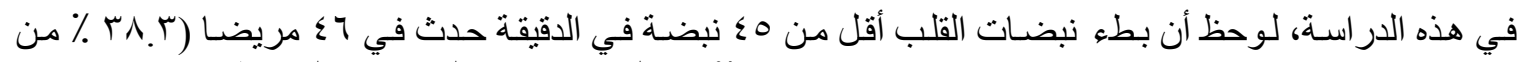

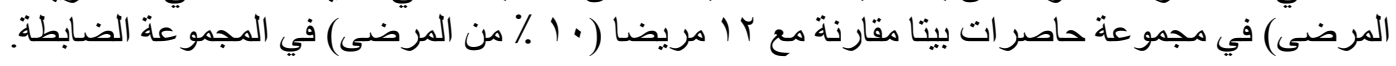

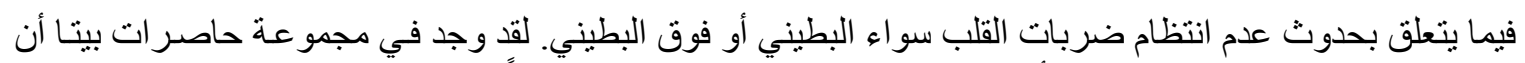

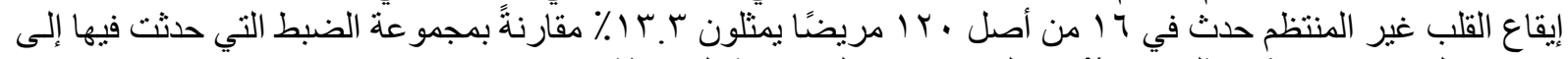

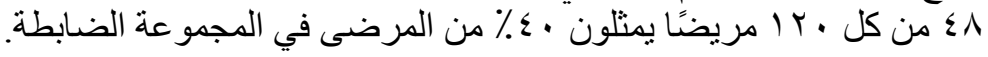
في هذه الدر اسة، أظهرت النتائج عدم وجود فرق بين المجمو عنين فيما يتعلق بالأحداث الدماغية و فثنل القلب. 


$$
\text { حدثت حالات منساوية من الوفيات للمرضى في كلتا المجمو عنين. }
$$

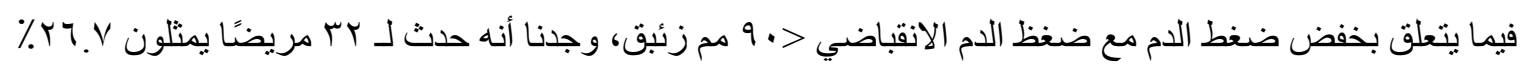

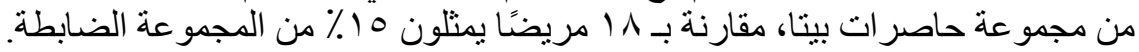
استنتاج

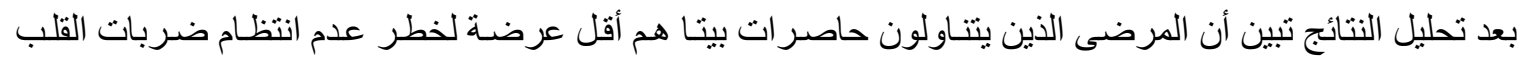

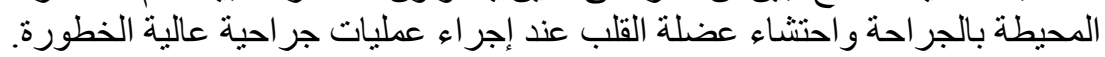

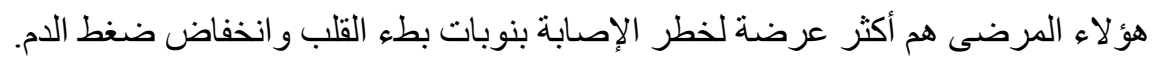
لا يوجد تأثير كبير على قصور القلب المحيطة بالجر احة والسكتة الدماغية و الوفيات. 